\title{
Jejunal microflora in malnourished Gambian children
}

\author{
B. HEYWORTH and J. BROWN \\ From Medical Research Council Laboratories, Fajara, The Gambia, West Africa
}

\begin{abstract}
Heyworth, B., and Brown, J. (1975). Archives of Disease in Childhood, 50, 27. Jejunal microflora in malnourished Gambian children. Jejunal intubation was carried out in 25 cases of malnutrition. Growth of bacteria greater than $10^{5}$ organisms $/ \mathrm{ml}$ was found in 22 children, of whom 17 gave a history of chronic diarrhoea. The other 8 children had either no diarrhoea or were having an acute attack lasting for a few days. In those with chronic diarrhoea, Esch. coli, bacteroides, and enterococci tended to occur more frequently, whereas streptococci occurred more frequently in those with acute diarrhoea. Bacilli, staphylococci, micrococci, klebsiellas, pseudomonads, and candidas often occurred in both groups and in large numbers in those with chronic diarrhoea. This confirms previous reports in other parts of the world that some children with malnutrition have considerable bacterial contamination of the jejunum, and that this may be of aetiological significance as a cause of much of the diarrhoea seen in malnourished children. It is possible too that this may be important in the pathogenesis of malnutrition. The presence of intestinal parasites in these malnourished children is also noted.

A double-blind trial in the use of antibiotics in this condition is advocated to determine whether it is possible to break the diarrhoea-malabsorption-malnutrition cycle. At the same time the effect of simply removing the child to a more sanitary environment, together with an estimate of the natural clearance of bacteria from the upper intestine, should be evaluated.
\end{abstract}

Children with protein-calorie malnutrition (PCM) often have diarrhoea and the association of the two at the time of weaning is particularly noticeable (Scrimshaw, Taylor, and Gordon, 1968). Acute diarrhoea may precipitate the onset of kwashiorkor (Gopalan, 1956) and there may also be an overlap in the seasonal prevalence of gastroenteritis and kwashiorkor (Smythe, 1958). Malnutrition tends to be seasonal in The Gambia (McGregor et al., 1968), occurring mainly during the later part of the wet season (which lasts from mid-May to midNovember) and the first 2 or 3 months of the dry season. It is during the wet season that diarrhoea, together with other infections, is particularly severe and chronic. Chronic recurrent diarrhoea is often seen in children with PCM (Mukherjee and Jelliffe, 1955) and may be essentially limited to such children (Wittman and Hansen, 1965). Children with PCM studied here during the 1971 and 1972 seasons with particular reference to their immune status and function (results to be published) had chronic

Received 10 June 1974. diarrhoea but common pathogens were not consistently isolated from their faeces, though salmonellae, shigellae, pathogenic Esch. coli, and parasites, particularly Giardia and Strongyloides, were occasionally found. This is a common finding in all less developed countries where only $40 \%$ or less of cases of diarrhoea of early childhood is associated with a bacterial pathogen in the faeces (Scrimshaw et al., 1968). Even this may be a high figure, for the prolonged carriage of intestinal pathogens without associated symptoms is well known and the finding of such a pathogen does not necessarily mean that it is the cause of an attack of diarrhoea, particularly in children who are having recurrent diarrhoea (personal observation). The viruses which can be identified at present do not provide the full answer to the question of the aetiology of chronic diarrhoea of children living in developing countries. While they are found in about half of the children with diarrhoea, they are also found in about the same number of those without diarrhoea (Scrimshaw et al., 1968). Increased numbers of jejunal organisms, which are 
normally commensals in the lower intestine, can however cause diarrhoea, and Dammin and his co-workers after studying post-mortem findings suggested that malnourished children develop diarrhoea when the upper small intestine becomes so colonized (Dammin, 1965).

It has been suggested that bacteria in the jejunum could contribute to malnutrition by deaminating dietary protein (Jones et al., 1968) or by the degradation of amino acids by bacteria such as Esch. coli, bacteroides, and klebsiellas (Strauss, Donaldson, and Gardner, 1961), or possibly by the production of unconjugated bile acids (Dawson and Isselbacher, 1960) and the inability to absorb fat (Tebaqchali and Booth, 1967).
Therefore it was decided to carry out this investigation during one 'malnutrition season' on consecutive admissions in order to see whether there was bacterial overgrowth of the jejunum in Gambian children with PCM.

\section{Patients and methods}

Children were admitted to the ward of the Medical $\nRightarrow$ Research Council laboratories in Fajara. Nutritional $\vec{O}$ assessment was made on the basis of weight for age. The latter was accurately known, or in a few cases where age was estimated the error of estimate was believed to be not greater than one month. There was no selection of cases, except that 7 children were in extremis and 2 응 children were intubated but the tube failed to negotiate

Clinical details of 25 Gambian c\&ildr

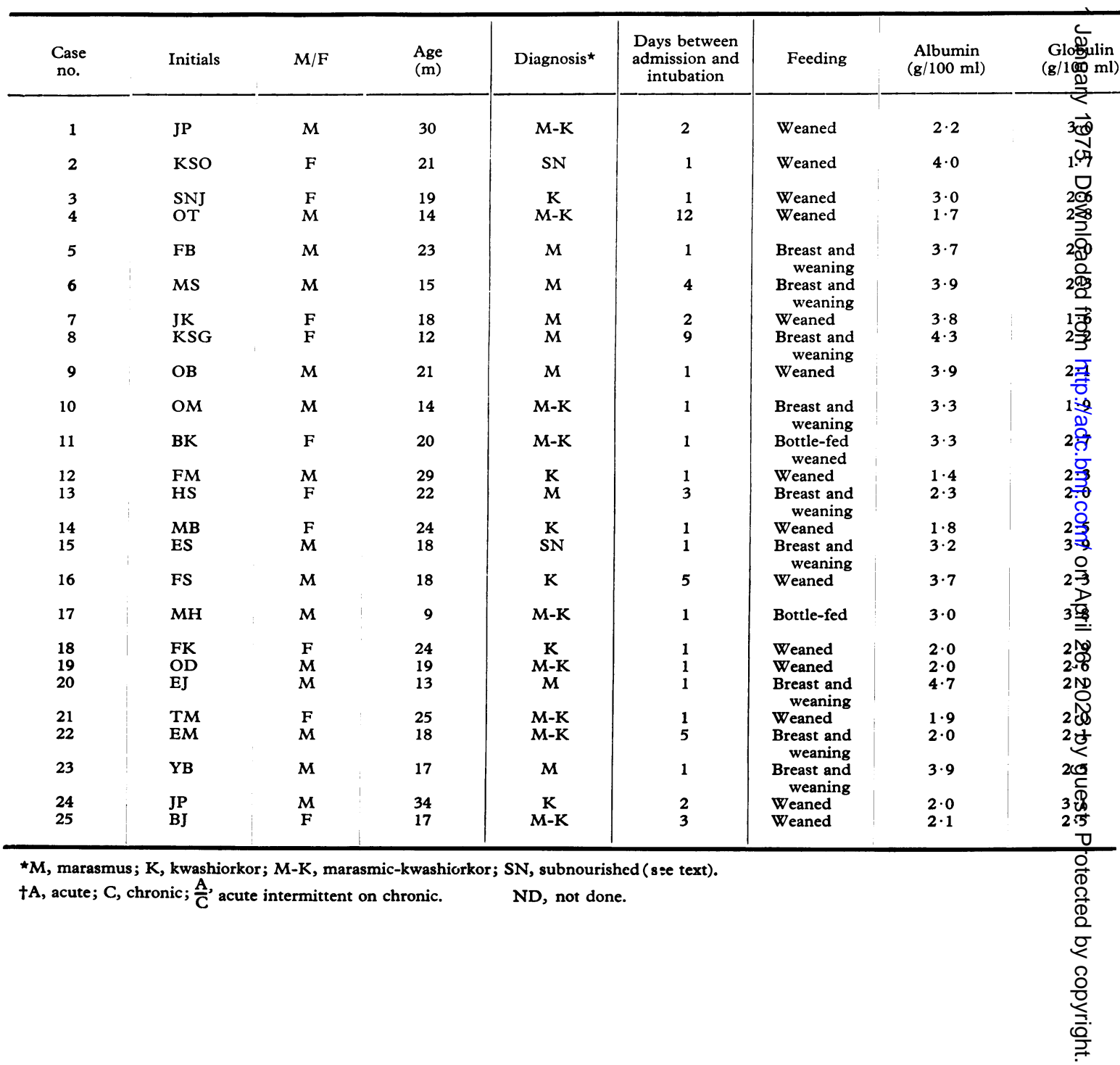


the pylorus. Additional parameters such as height, arm circumference, triceps skinfold thickness, and serum albumin were also determined and note was taken of oedema, skin changes, and hepatosplenomegaly.

The children were classified into kwashiorkor $(\mathbf{K})$, i.e. weight $60-80 \%$ of the Boston 50th centile, with oedema; marasmic-kwashiorkor (M-K), i.e. less than $60 \%$ of the Boston 50th centile, with oedema; marasmus $(M)$, i.e. less than $60 \%$ of the Boston 50th centile, without oedema; and subnourished (SN), i.e. $60-80 \%$ of the Boston 50th centile without oedema or other stigmata of kwashiorkor. Particular note was taken on admission of a history of diarrhoea and vomiting. A history of chronic diarrhoea was defined as persistent loose or watery stools usually at least 4 times per day and occurring continuously or intermittently in every week for at least 3 weeks. An acute attack of diarrhoea was defined as above except that there had been an interval of at least one week when the child's stools were normal. The history, as taken from the mother, was often confirmed by the sisters or doctor referring the case. It was known in most cases that broad-spectrum antibiotics had not been given and the one child who was undergoing such treatment was not intubated. A dietary history was also taken. Dehydration was assessed as mild, moderate, or severe according to the criteria of Ironside and his co-workers (Ironside, Tuxford, and Heyworth, 1970). If present, this was corrected by oral half-strength Darrow's solution (without glucose) before the intubation was carried out. A summary of the main clinical details is given in Table I.

Intubation. Jejunal intubation was carried out using a paediatric biopsy capsule threaded through a

vith protein-calorie malnutrition

\begin{tabular}{|c|c|c|c|c|c|c|c|}
\hline \multirow{2}{*}{$\underset{(\mathbf{g} / \mathrm{dl})}{\mathrm{Hb}}$} & \multirow{2}{*}{ PCV } & \multicolumn{2}{|c|}{ History of stools } & \multirow{2}{*}{$\begin{array}{l}\text { Carmine transit } \\
\text { time } \\
(\mathrm{h})\end{array}$} & \multirow{2}{*}{$p \mathrm{H}$} & \multirow{2}{*}{ Stool } & \multirow{2}{*}{ Comments } \\
\hline & & Diarrhoea $†$ & Days & & & & \\
\hline $11 \cdot 6$ & 35 & $\begin{array}{l}\text { A } 7 \mathrm{dy} \\
\mathrm{C} \quad 3 \mathrm{wk}\end{array}$ & 6 & ND & $8 \cdot 0$ & & \\
\hline $10 \cdot 2$ & 38 & $\begin{array}{l}\text { A } 3 d y \\
\bar{C} \quad 3 w k\end{array}$ & 4 & 13 & $7 \cdot 5$ & & Mild dehydration \\
\hline $\begin{array}{r}5 \cdot 4 \\
10 \cdot 4\end{array}$ & $\begin{array}{l}22 \\
36\end{array}$ & $\begin{array}{l}\text { C } 6 \text { wk } \\
\text { C } 4 \text { wk }\end{array}$ & $\begin{array}{l}5 \\
4\end{array}$ & $\begin{array}{l}\text { ND } \\
10 \cdot 5\end{array}$ & $\begin{array}{l}8 \cdot 0 \\
8 \cdot 5\end{array}$ & Strongyloides & $\begin{array}{l}\text { Salmonellae in blood } \\
\text { Treated before }\end{array}$ \\
\hline $10 \cdot 2$ & 35 & $\begin{array}{l}\text { A } 7 \mathrm{dy} \\
\bar{C} \quad 8 \text { wk }\end{array}$ & 4 & 6 & $9 \cdot 0$ & & \\
\hline $6 \cdot 8$ & 32 & C 4 wk & 5 & 11 & $9 \cdot 0$ & & \\
\hline $\begin{array}{l}13 \cdot 2 \\
11 \cdot 0\end{array}$ & $\begin{array}{l}47 \\
34\end{array}$ & $\begin{array}{l}\text { C } 8 \text { wk } \\
\text { C } 8 \text { wk }\end{array}$ & $\begin{array}{l}4 \\
7\end{array}$ & $\begin{array}{r}13 \\
9\end{array}$ & $\begin{array}{l}9 \cdot 0 \\
8 \cdot 5\end{array}$ & & Mild dehydration \\
\hline $13 \cdot 6$ & 41 & C $8 w k$ & 7 & 6 & $8 \cdot 5$ & Giardia & $\begin{array}{l}\text { Giardia in jejunum; } \\
\text { mild dehydration }\end{array}$ \\
\hline $11 \cdot 1$ & 36 & C 12 wk & 5 & 11 & $7 \cdot 0$ & & Mild dehydration \\
\hline $8 \cdot 3$ & 28 & C 12 wk & 7 & 6 & $8 \cdot 5$ & & \\
\hline $\begin{array}{r}8 \cdot 6 \\
10 \cdot 0\end{array}$ & $\begin{array}{l}38 \\
40\end{array}$ & $\begin{array}{l}\text { C } 3 \text { wk } \\
\text { C } 4 \text { wk }\end{array}$ & $\begin{array}{l}4 \\
6\end{array}$ & $\begin{array}{r}10 \\
5\end{array}$ & $\begin{array}{l}7 \cdot 5 \\
7 \cdot 5\end{array}$ & Giardia & $\begin{array}{l}\text { Died } \\
\text { Mild dehydration; } \\
\text { died }\end{array}$ \\
\hline $\begin{array}{l}8 \cdot 8 \\
5 \cdot 3\end{array}$ & $\begin{array}{l}31 \\
17\end{array}$ & $\begin{array}{l}\text { C } 4 \text { wk } \\
\text { C } 8 \text { wk }\end{array}$ & $\begin{array}{l}4 \\
4\end{array}$ & $\begin{array}{r}16 \\
7\end{array}$ & $\begin{array}{l}8 \cdot 2 \\
8 \cdot 5\end{array}$ & & \\
\hline $8 \cdot 0$ & 29 & $\begin{array}{l}\text { A } 5 \text { dy } \\
\text { C } 8 \text { wk }\end{array}$ & 7 & $5 \cdot 5$ & $8 \cdot 5$ & Shigella fiexneri & \\
\hline $10 \cdot 2$ & 37 & $\frac{\mathrm{A}}{\mathrm{C}} \mathbf{\mathrm { mth }}$ & 8 & ND & $7 \cdot 5$ & & Mild dehydration \\
\hline $\begin{array}{r}8 \cdot 3 \\
8 \cdot 0 \\
13 \cdot 4\end{array}$ & $\begin{array}{l}25 \\
31 \\
42\end{array}$ & $\begin{array}{l}\text { A } 4 \mathrm{dy} \\
\text { A } 1 \mathrm{dy} \\
\text { A } 4 \mathrm{dy}\end{array}$ & $\begin{array}{l}4 \\
4 \\
7\end{array}$ & $\begin{array}{l}23 \\
20 \\
\text { ND }\end{array}$ & $\begin{array}{l}8 \cdot 2 \\
8 \cdot 5 \\
7 \cdot 0\end{array}$ & & $\begin{array}{l}\text { Salmonellae in blood } \\
\text { Moderate dehydration }\end{array}$ \\
\hline $\begin{array}{l}7 \cdot 2 \\
9 \cdot 3\end{array}$ & $\begin{array}{l}23 \\
32\end{array}$ & $\begin{array}{l}\text { A } 10 \mathrm{dy} \\
\text { A } 6 \mathrm{dy}\end{array}$ & $\begin{array}{l}6 \\
4\end{array}$ & $\begin{array}{r}7 \\
12\end{array}$ & $\begin{array}{l}9 \cdot 0 \\
8 \cdot 2\end{array}$ & Giardia & Mild dehydration \\
\hline $6 \cdot 8$ & 20 & $\mathrm{Nil}$ & 3 & 8 & $8 \cdot 0$ & & \\
\hline $\begin{array}{l}6 \cdot 1 \\
9 \cdot 3\end{array}$ & $\begin{array}{l}20 \\
30\end{array}$ & $\begin{array}{l}\text { A } 7 \mathrm{dy} \\
\text { A } 6 \mathrm{dy}\end{array}$ & $\begin{array}{l}4 \\
5\end{array}$ & $21^{6 \cdot 5}$ & $\begin{array}{l}8 \cdot 5 \\
8 \cdot 0\end{array}$ & Giardia & Giardia in jejunum \\
\hline
\end{tabular}


polyvinyl tube (James, 1968). The child was sedated by intravenous diazepam after a fast of at least 4 hours and usually overnight. When the tube was passed into the oesophagus the child was placed in the full-prone position. No radiological control was available, but the tube passed easily through the pylorus after introducing about $100 \mathrm{ml}$ of air and using gentle abdominal massage. A change in $p H$ and the aspiration of bile occurred usually after 15-45 minutes, whereupon the tube was advanced a further $15 \mathrm{~cm}$ to lie between $45-50 \mathrm{~cm}$ from the teeth, depending upon the size of the child. Specimens of jejunal fluid were then aspirated from that area. Most children slept, or were unconcerned, throughout the whole procedure. In order to 'flush-out' the tube the first $5 \mathrm{ml}$ or so of the aspirate were discarded before specimens were taken and sent straight to the laboratory for bacterial examination. Further specimens were collected for secretory $\operatorname{IgA}$, and a biopsy was taken. These will be reported later. A gelatin capsule containing about $150 \mathrm{mg}$ carmine red was given to determine the transit time, and records were kept of stools passed for at least 3 days after, as well as before, the intubation. These results are also included in the clinical summary in Table I. No case of haemorrhage or perforation occurred.

Bacteriological technique. This was similar to that used by Parkin and his colleagues (Parkin et al., 1972) with slight modifications. Within 5 minutes of the specimens being aspirated, $0.1 \mathrm{ml}$ jejunal fluid was placed into $0.9 \mathrm{ml}$ glucose broth, using a micropipette and the contents were mixed. Serial dilutions were made up to $10^{-5}$. From the undiluted fluid and from each dilution $10 \mu \mathrm{l}$ were placed around each plate of a variety of nonselective and selective media, again using a micropipette, and these were cultured. The media used and times of culture are shown in Table II. Evacuation of air from the anaerobic jars was carried out at $70 \mathrm{~cm}$ $\mathrm{Hg}$ with a vaccuum pump, and $95 \%$ hydrogen and $5 \%$ $\mathrm{CO}_{2}$ was produced using Gaspaks (B.B.L. Becton
Dickinson, U.K.). The whole procedure took less than 30 minutes. Each colony type after isolation was Gram-stained and all organisms isolated anaerobically were tested for their ability to grow aerobically on blood agar. Organisms were identified according to Cowan and Steele (1965). Counts were usually done by one of us (J.B.) without prior knowledge of the history; further examination was then done by both authors.

\section{Results}

Table I shows the main clinical features of each case together with some investigations and laboratory data. There was no significant difference between subjects with acute and chronic diarrhoea with respect to age, sex, nutritional classification, feeding, number of stools passed, serum albumin, $\mathrm{Hb}, \mathrm{PCV}$, stool pathogens, $\mathrm{pH}$ of the jejunal fluid, or carmine transit time.

Fig. 1 shows the mean and standard deviation (SD) of the total facultative anaerobes in those with chronic and acute diarrhoea, and the actual counts of the children in each group. Bacterial counts of facultative anaerobes of over $1.0 \times 10^{5}$ were found in 22 children, but 16 children who gave a history of chronic diarrhoea had counts of this magnitude and the other child (Case 6) had a growth of bacteroides of over $1.0 \times 10^{6}$, though the count of his facultative anaerobes was very low. All 25 children showed a variety of organisms, usually of 3 or 4 types. Those children with a massive overgrowth $\left(>1 \times 10^{10}\right)$ had a preponderance usually of only 1 or 2 types. Analysis of the total facultative anaerobes in those with a history of chronic diarrhoea showed a higher mean count than those with acute diarrhoea (Fig. 1, $\mathrm{P}<0.005$, Student's ' $\mathrm{t}$ ' test).

TABLE II

Bacterial culture technique

\begin{tabular}{|c|c|c|c|}
\hline Medium & Incubation & $\begin{array}{l}\text { Duration } \\
\text { (d) }\end{array}$ & Organisms counted \\
\hline $\begin{array}{l}\text { (1) } 7 \% \text { blood agar } \\
\text { (2) } 7 \% \text { blood agar } \\
\text { (3) MacConkey agar } \\
\text { (4) Mannitol-salt agar } \\
\text { (5) Sabouraud agar } \\
\text { (6) China-blue lactose agar } \\
\text { (7) Rogosa agar } \\
\text { (8) Tomato-juice agar } \\
\text { (9) } 7 \% \text { blood agar with } 100 \mu \mathrm{g} / \mathrm{ml} \text { neomycin and } \\
7.5 \mu \mathrm{g} / \mathrm{ml} \text { vancomycin } \\
\text { (10) Veillonella agar } \\
\text { (11) Willis and Hobbs medium with } 100 \mu \mathrm{g} / \mathrm{ml} \\
\text { neomycin } \\
\text { Replaced later by } \\
\text { (11) Reinforced clostridial agar with } 100 \mu \mathrm{g} / \mathrm{ml} \\
\text { neomycin }\end{array}$ & $\begin{array}{l}\text { Aerobically } \\
\text { Anaerobically } \\
\text { Aerobically } \\
\text { Aerobically } \\
\text { Aerobically } \\
\text { Aerobically } \\
90 \% \mathrm{CO}_{2} \\
\text { Anaerobically } \\
\text { Anaerobically } \\
\text { Anaerobically } \\
\text { Anaerobically } \\
\text { Anaerobically }\end{array}$ & $\begin{array}{l}1 \\
5 \\
1 \\
1 \\
1 \\
1 \\
2 \\
2 \\
2 \\
2 \\
2\end{array}$ & $\begin{array}{l}\text { Total aerobes } \\
\text { Total anaerobes } \\
\text { Coliforms/enterococci } \\
\text { Staphylococci } \\
\text { Candidas } \\
\text { Lactose and nonlactose fermenters } \\
\text { Lactobacilli } \\
\text { Anaerobic lactobacilli } \\
\text { Bacteroides } \\
\text { Veillonella } \\
\text { Clostridia } \\
\text { Clostridia }\end{array}$ \\
\hline
\end{tabular}




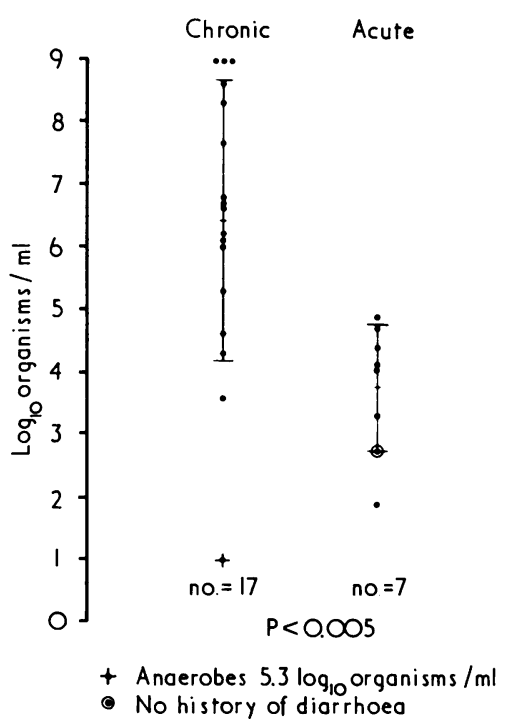

FIG. 1.-Mean $\pm S D$ of total facultative anaerobes in jejunal fluid of children with PCM and acute or chronic diarrhoea.

Fig. 2 shows the distribution of counts of various organisms isolated in the two groups of children. It can be seen that those with chronic diarrhoea had a tendency, which did not quite reach statistical significance, to show a growth of Esch. coli, bacteroides, and enterococci; whereas it is significant $\left(\mathbf{P}<0.05, \chi^{2}\right.$ test) that streptoccocci were more prevalent in those with acute diarrhoea than in those with a history of chronic diarrhoea. Staphylococci, micrococci, klebsiellas, pseudomonads, candidas, and particularly bacilli were common to both groups. A further 9 organisms were isolated from some patients in each group.

Giardia was found in the jejunum of 1 child with chronic diarrhoea (Case 9) and in 1 with acute diarrhoea (Case 24) and the nutritional state of both children improved after treatment of this infection. The latter child was admitted twice (Cases 1 and 24) during a 4-month period. His weight gain after the first admission had been reasonably satisfactory, but another attack of diarrhoea precipitated his kwashiorkor.

Strongyloides occurred in 1 child (Case 4) and was treated before intubation was carried out. In spite of this delay, the count in the jejunum was still over $1.0 \times 10^{6}$, and the diarrhoea had peristed, though there was some improvement in the nutritional state after the Strongyloides was eradicated.

None of the Esch. coli were type specific when this
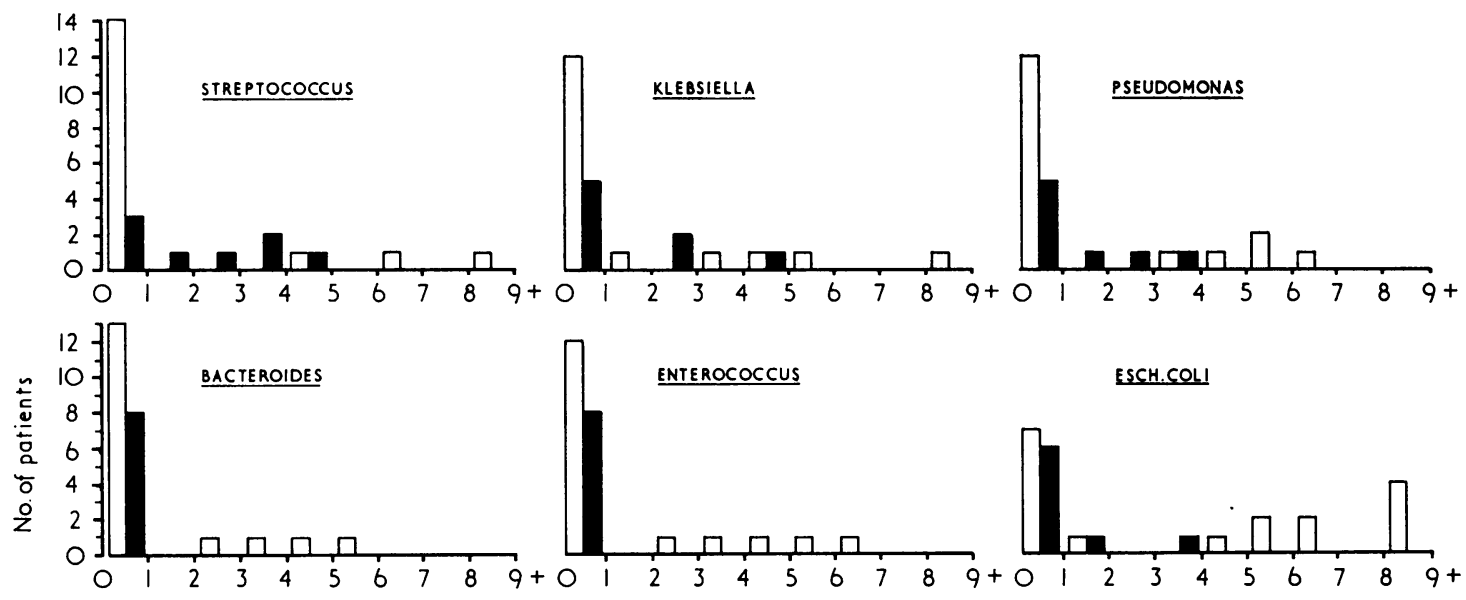

ESCH.COLI
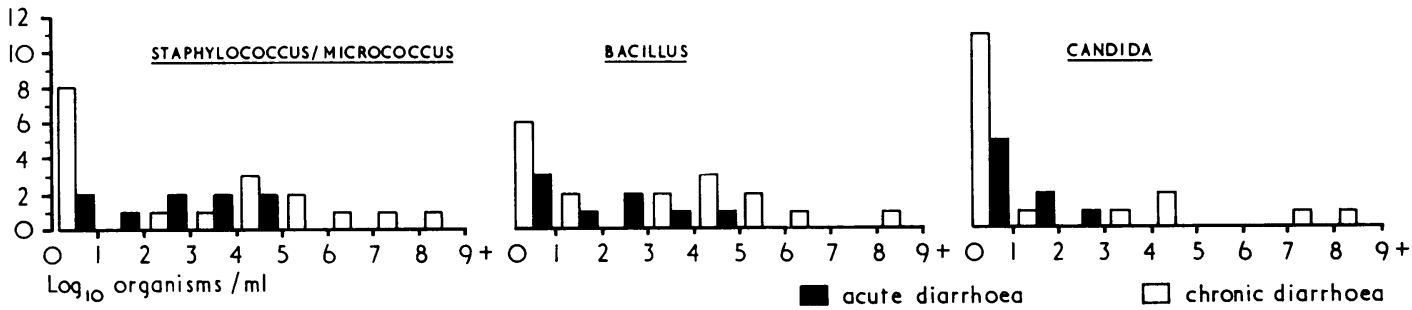

FIG. 2.-Distribution of counts in PCM. 
was done by slide agglutination using commercial polyvalent antisera. Salmonellae were present in the blood cultures of 2 children (Cases 3 and 18) but were not isolated from the jejunum. Shigella flexneri (type 2) was present in the faeces of 1 child (Case 16) but was not identified in the jejunal sample. Giardia was found in the faeces but not the jejunal aspirate of 2 children, one before (Case 12) and one after (Case 21) intubation. These infections were not heavy.

The carmine was given in the fasting state and fluids only were given for several hours after biopsy; therefore some of the transit times are more prolonged than the diarrhoea would suggest.

\section{Discussion}

James, Drasar, and Miller (1972) found no correlation between the numbers or types of jejunal organisms and the nutritional state of his patients in Jamaica. Most of these had small numbers of mixed aerobicand anaerobic organisms, though 4 had a total count above $10^{4}$ organisms $/ \mathrm{ml}$.

However, an increase in jejunal microflora has been described by Mata et al. (1972) in Guatemalan children. His 4 'normal' controls had counts similar to those seen in our series with acute diarrhoea and PCM and 1 of his normals actually had a count of $10^{8}$ Esch. coli and $10^{5}$ bacteroides. The organisms were also similar to those in our subjects with a history of acute diarrhoea, being mainly streptococci. His cases of PCM with diarrhoea were very similar to those in our series who had chronic dirarhoea, except that he found bacteroides to be more common in those without diarrhoea on admission. His children had a greater incidence of Giardia and unlike him we found no hookworm, Ascaris, or Entamoeba histolytica in our cases.

One further report also describes jejunal bacteria in Australian aboriginal children with PCM and chronic diarrhoea (Gracy and Stone, 1972). The organisms, both in quantity and type were very similar to those we isolated except that we found a greater number of anaerobes, particularly in those with chronic diarrhoea. They also found many children with Giardia in their faeces.

It is possible that the children with acute diarrhoea had lower counts because of a dilution factor caused by marked accumulation of fluid in the jejunum. This accumulation (i.e. due to net secretion) was shown by perfusion studies by James et al. (1972). It is not known whether this applies to those with chronic diarrhoea and certainly there was nothing to suggest that those with acute diarrhoea in our series had a greater flow of jejunal fluid up the tube than those with chronic diarrhoea.

Even in those with acute diarrhoea the counts were greater than $10^{4}$ in 6 children and it may be that these would have gone on to chronic diarrhoea if they had not been hospitalized; or, as has been suggested by Mata et al. (1972), these counts may possibly indicate the generally poor level of hygiene in the community from which they were drawn. Well nourished children with acute diarrhoea coming from similar communities are being studied.

The finding of 2 bottle-fed children (Cases 11 and 17) among those with chronic diarrhoea is not statistically significant but perhaps confirms the clinical impression that this is a pernicious imported practice often resulting in chronic diarrhoea.

Antibiotics have been advocated because of the suggestion that they will break the diarrhoeamalabsorption-malnutrition cycle (Hirschhorn, 1971). This has been tried with certain antibiotics in minimal dosage, particularly tetracycline, with some success (MacDougall, 1957), but it has been pointed out that this is only beneficial for a limited period of time, i.e. for about 6 months (Guzman, Scrimshaw, and Monroe, 1958). If this were true, however, it would be of benefit to children who live in areas such as this where PCM tends to be seasonal. Certainly some of those treated in our series, especially those who had high counts of bacteroides, improved dramatically when the correct antibiotic was given. But it is notoriously difficult to assess the effect of antibiotics even in specific gastrointestinal infections in developed countries (Heyworth, 1970). It may be that removing the child to a more sanitary environment could be the correct treatment, to permit natural clearance of organisms from the jejunum. Indeed one child (Case 15) had a growth of $10^{9} / \mathrm{ml} \mathrm{Esch}$. coli but because his nutritional state was reasonably good he was not treated. His diarrhoea improved spontaneously and he gained weight. After only 1 week repeated intubation showed a total growth of only $10^{5}$ organisms with the complete elimination of Esch. coli and their replacement with streptococci and bacilli. It was also noticeable that even in those with chronic diarrhoea who were not given broad-spectrum antibiotics, their diarrhoea improved and their weight increased while in hospital.

A reduction in the microflora with dietary treatment as observed by Mata et al. (1972) may be the result of such a natural clearance of the jejunum on removing the child from his home environment.

It seems that parasites such as Giardia and

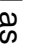


Strongyloides appear to be important causes of chronic diarrhoea in some cases, though the frequency of their occurrence obviously varies from place to place. Another child, not included in the series, was recovering from kwashiorkor but showed little weight gain and occasional diarrhoea. Intubation showed a massive infestation with Giardia and Strongyloides and a mixed staphylococcal/pseudomonad/streptococcal growth of $10^{4}$ organisms $/ \mathrm{ml}$. In this case treatment of the parasitic infection produced rapid weight gain.

A properly conducted double-blind trial of suitable broad-spectrum antibiotics, perhaps on a multi-centred basis, should be carried out. No doubt this would present problems because many children with PCM require antibiotics for other infections, multiple pathology being especially common.

We thank Dr. I. A. McGregor, previous Director, and Dr. R. S. Bray, present Director, of the MRC Laboratories for encouragement and advice; and the sisters and nurses of the ward for their practical help and the care of our patients.

\section{REFERENCES}

Cowan, S. T., and Steele, K. J. (1965). Manual for Identification of Medical Bacteria. Cambridge University Press.

Dammin, G. J. (1965). Pathogenesis of acute clinical diarrheal disease. Federation Proceedings, 24, 35.

Dawson, A. M., and Isselbacher, K. J. (1960). Studies on lipid metabolism in the small intestine with observations on the role of bile salts. Fournal of Clinical Investigation, 39, 730.

Gopalan, C. (1956). Kwashiorkor in Uganda and Coonoor. Fournal of Tropical Paediatrics, 1, 206.

Gracey, M., and Stone, D. E. (1972). Small-intestinal microflora in Australian aboriginal children with chronic diarrhoea. Australia and New Zealand fournal of Medicine, 2, 215.

Guzman, M. A., Scrimshaw, N. S., and Monroe, R. J. (1958). Growth and development of the central American child. I. Growth responses of rural Guatemalan school children to daily administration of penicillin and auromycin. American fournal of Clinical Nutrition, 6, 430.
Heyworth, B. (1970). Colistin and other antibiotics in the treatment of specific gastrointestinal infections. Medical Officer, 123, 349.

Hirschhorn, N. (1971). Can small daily doses of antibiotics prevent the diarrhea, malabsorption, and malnutrition in children? American fournal of Clinical Nutrition, 24, 872.

Ironside, A. G., Tuxford, A. F., and Heyworth, B. (1970). A survey of infantile gastroenteritis. British Medical fournal, 3, 20.

James, W. P. T. (1968). Jejunal biopsy modified for paediatric use. Lancet, 1, 795.

James, W. P. T., Drasar, B. S., and Miller, C. (1972). Physiological mechanism and pathogenesis of weanling diarrhea. American Fournal of Clinical Nutrition, 25, 564.

Jones, E. A., Craigie, A., Tavill, A. S., Franglen, G., and Rosenoer, V. M. (1968). Protein metabolism in the intestinal stagnant loop system. Gut, 9, 466 .

MacDougall, L. G. (1957). Effect of aureomycin on undernourished African children. Fournal of Tropical Paediatrics, 3, 74.

McGregor, I. A., Rahman, A. K., Thompson, B., Billewicz, W. Z., and Thomson. A. M. (1968). The growth of young children in a Gambian village. Transactions of the Royal Society of Tropical Medicine and Hygiene, 62, 341.

Mata, L. J., Jimenez, F., Cordon, M., Rosales, R., Prera, E., Schneider, R. E., and Viteri, F. (1972). Gastro-intestinal flora of children with protein-calorie malnutrition. American fournal of Clinical Nutrition, 25, 118.

Mukheriee, K. L., and Jelliffe, D. B. (1955). Clinical observations on kwashiorkor in Calcutta. Fournal of Tropical Paediatrics, 1, 61.

Parkin, D. M., McClelland, D. B. L., O'Moore, R. R., Percy-Robb, I. W., Grant, I. W. B., and Shearman, D. J. C. (1972). Intestinal bacterial flora and bile salt studies in hypogammaglobulinaemia. Gut, 13, 182.

Scrimshaw, N. S., Taylor, C. E., and Gordon, J. E. (1968). Interactions of nutrition and infection. World Health Organization Monograph Series No. 57, Geneva.

Smythe, P. M. (1958). Changes in intestinal bacterial flora and role of infection in kwashiorkor. Lancet, 2, 724.

Strauss, E. W., Donaldson, R. M. Jr., and Gardner, F. H. (1961). Relationship between intestinal bacteria and the absorption of vitamin $B_{12}$ in rats with diverticula of the small bowel. Lancet, 2, 736.

Tabagchali, S, and Booth C. C. (1967). The relationship of the intestinal bacterial flora to absorption. British Medical Bulletin, 23, 285.

Wittman, W., and Hansen J. D. L. (1965). Gastroenteritis and malnutrition. South African Medical.fournal, 39, 223.

Dr. B. Heyworth, Department of Tropical Child Health, Liverpool School of Tropical Medicine, Pembroke Place, Liverpool L3 5QA. 